\title{
FIBER CLASSIFICATION, PHYSICAL AND OPTICAL PROPERTIES OF RECYCLED PAPER
}

\author{
UFUK YILMAZ*, AHMET TUTUŞ ${ }^{*}$ and SINAN SÖNMEZ ${ }^{* *}$ \\ "Forest Industry Engineering, Kahramanmaras Sutcu Imam University, \\ 46050, Kahramanmaraş, Turkey \\ **Applied Sciences/Department of Printing Technologies, Marmara University, \\ 34722, Istanbul, Turkey \\ × Corresponding author: Ufuk Yllmaz, kufu27@ hotmail.com
}

Received September 23, 2020

In this study, reference papers prepared in accordance with the INGEDE 11p standard (International Association of the Deinking Industry) were recycled three times. Initially, reference papers were subjected to wetting, pulping, storage, deinking, dispersing and bleaching processes. At the end of these processes, test papers were produced and their optical characteristics were examined. The brightness value of writing papers (of 80 grams) was determined to be of $86 \%$, following the TS 11610:2017 standard. In order to bring the brightness of the produced laboratory test papers to the specified value, double-stage bleaching was applied: with $0.4 \%$ FAS in the first stage and $\mathrm{H}_{2} \mathrm{O}_{2}$ in the second stage. The physical and optical properties of the test papers that reached the standard brightness value were determined. Overall, the final products were recycled three times. At the end of the third recycling stage, changes in paper fibers were examined.

As a result, it was observed that the breaking, tear and burst resistance of the obtained papers gradually decreased at the end of each recycling stage. In addition, because of the narrowing fiber surface, it was determined that the opacity value of the paper decreased at the end of each recycling stage. According to the fiber classification results, the fiber size shrank at the end of the third recycling stage and a large part of the fibers remained in the 200 mesh. Paper fibers are recycled 3.6 times in Europe. This rate is approximately 2.4 times higher than the world average. This study offers interesting results regarding cellulose recycling, which has gained great importance in recent years.

Keywords: INGEDE, recycling, optical properties, physical properties, fiber classification

\section{INTRODUCTION}

The production of paper and cardboard products continues to increase steadily on a global level. The total production of paper and cardboard products, which was 399.06 million tons in 2012, reached 412.64 million tons in 2017. The production of paper and cardboard products has grown by an annual average of 0.67 percent during this period. Globally, the annual average growth rate has stabilized below 1.0 percent in recent years. ${ }^{1}$

As forest resources are decreasing, while the demand for paper is constantly and rapidly increasing, the recycling of waste paper and its reuse for paper products in order to meet this demand has gained prominence, especially under the leadership of Japan and Western Europe. ${ }^{2}$ $72.5 \%$ of the paper consumed in Europe in 2016 was recycled. This rate was $71.9 \%$ in 2015 .
Compared to 2015, the collection of paper for recycling increased by $0.9 \%$, reaching 59.5 million tons. In 2016, the number of countries that recycled below $60 \%$ fell to 9 . Currently, paper recycling is over $70 \%$ in 17 countries. In Europe, paper fibers are recycled 3.6 times on average. This rate is approximately 2.4 times higher than the world average. The amounts of waste paper recycled globally between 1960 and 2018 are presented in Figure 1. ${ }^{3}$ The graph illustrates the continuous growth of the recycling rate over the years. While the recycling rate was $5 \%$ on a global level in the 1960s, this rate exceeded $45 \%$ in 2018.

Recycling should be a preferred approach, considering existing environmental issues, when appropriate clean technologies are used. Fibrous wastes come from a wide variety of products. The 
cooperation between the private sector, the government and universities would encourage an increase of the recovery rate. ${ }^{5}$

However, recycling also poses some serious challenges for the paper industry. To recycle paper, deinking has to be performed to improve the final color and overall quality of the recycled paper. Ink removal constitutes the major technical obstacle in converting this raw material into quality products. ${ }^{5}$ Among the various deinking methods, chemicals such as peroxides, caustic soda and surfactants, are commonly used. ${ }^{6}$ A generally preferred method for removing detached particles from the pulp is flotation. ${ }^{7}$ Ink detachment occurs when chemical and mechanical actions release ink from the fiber. If ink particles are not removed from the pulp, recycled paper will not only have poor optical and mechanical properties, but also it can cause problems because of the presence of toxic substances. ${ }^{8}$

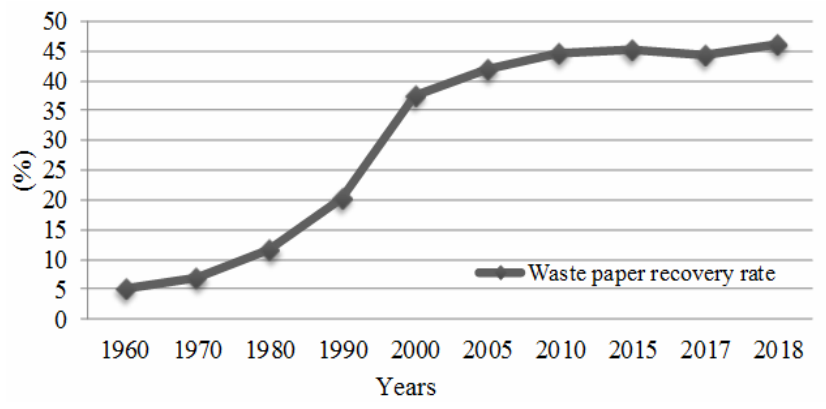

Figure 1: Global waste paper recovery rate

Another challenge is for the paper product to meet the mechanical, physical and printing requirements, while the quality of the recycled paper is decreasing. ${ }^{9}$ Cellulose is a biodegradable material. The chemicals used during recycling and drying processes in paper production cause the fiber hornification. This morphological and chemical change in the cellulose structure causes irreversible degradation. ${ }^{10-13}$ In some studies on this subject, Nazhad and Pazner ${ }^{14}$ examined the effect of drying temperature on recycled paper and concluded that the drying process is the main cause of degradation in the recycling process of paper. M. Lima et al. ${ }^{15-16}$ stated that the strength properties of paper are strongly affected by the drying method and process conditions. On the other hand, Blaznik et $a l^{17}$ consider that temperature alone has no effect on the reflectance curves of paper. In order to increase the usability of cellulose fibers, different strategies should be developed to reduce cellulose degradation during recycling.

In this study, the way the number of waste paper recycling runs affects the fiber properties is examined. In this investigation, the optical properties, physical properties and fiber dimensions of the paper were tested and analyzed by various methods. In addition, at the end of each recycling stage, the extent to which the fiber dimensions of the paper are altered has been studied.

Deeper knowledge of recycling and recycled paper can enhance the efficiency of the recycling process and thus, thousands of trees cut down for paper production every year could be saved. In addition, it is known that the energy consumed for paper production is much higher than the energy and water used for recycling. Thus, as the recycling rate increases, the amount of energy and water savings will increase.

\section{EXPERIMENTAL \\ Materials}

In this study, reference papers prepared in accordance with the INGEDE (method 11p-5.5) standard and printed with water-based inks were used for recycling.

\section{Methods}

\section{Pulping process}

The reference papers prepared in accordance with the INGEDE standard were manually cut to $2 \times 2 \mathrm{~cm}$ pieces. Then, the shredded papers were turned into pulp in a Hobart type pulping device, following the conditions in Table $1 .{ }^{18}$ Sodium hydroxide $(0.6 \%)$, hydrogen peroxide $(0.7 \%)$, sodium silicate $(1.8 \%)$ and oleic acid $(0.8 \%)$ were used in the pulping process. 
After the pulping process, the pulps were kept in a water bath at $45{ }^{\circ} \mathrm{C}$ and $5 \%$ fiber concentration $(5 \%$ dry fiber in the suspension) for 1 hour.

Table 1

Pulping conditions for waste office papers

\begin{tabular}{lccc}
\hline Pulping conditions & Level & Fiber concentration $(\%)$ & Time $(\mathrm{min})$ \\
\hline Prewetting & - & 10 & 10 \\
Pulping & $1-2$ & 10 & 22 \\
\hline
\end{tabular}

Table 2

Flotation conditions for waste office papers

\begin{tabular}{lc}
\hline Flotation conditions & \\
\hline Fiber concentration & $1 \%$ \\
Temperature & $45^{\circ} \mathrm{C}$ \\
Time & $30 \mathrm{dk}$ \\
Mixing speed & $1450 \mathrm{rev} / \mathrm{min}$ \\
Water hardness & $160 \mathrm{ppm}$ \\
Air intake & $2.5 \mathrm{~L} / \mathrm{min}$ \\
\hline
\end{tabular}

Table 3

Bleaching conditions for waste office papers

\begin{tabular}{lcc}
\hline Bleaching conditions & Stage I & Stage II \\
\hline $\mathrm{H}_{2} \mathrm{O}_{2}(\%)$ & - & 7 \\
$\mathrm{MgSO}_{4}(\%)$ & - & 0.5 \\
$\mathrm{EDTA}(\%)$ & - & 0.5 \\
$\mathrm{Na}_{2} \mathrm{SiO}_{3}(\%)$ & - & 2 \\
Fiber concentration $(\%)$ & 5 & 12 \\
Temperature $\left({ }^{\circ} \mathrm{C}\right)$ & 75 & 75 \\
Time (min) & 60 & 60 \\
$\mathrm{NaOH}(\%)$ & 0.2 & 5.25 \\
FAS $(\%)$ & 0.4 & - \\
\hline
\end{tabular}

\section{Flotation process}

After pulping, in order to remove the ink from the pulp, a flotation process was performed 6 times during 3 stages under the conditions specified in Table 2.

\section{Bleaching and calendering}

In the first stage of the bleaching process, formamidine sulfunic acid (FAS) was applied to the pulp obtained after the procedure described above. After bleaching, test paper was produced from the pulp obtained and its optical properties were examined. Since the pulp did not reach the brightness specified in the standard, the hydrogen peroxide $\left(\mathrm{H}_{2} \mathrm{O}_{2}\right)$ bleaching process was applied to the same pulps as a second step. The applied bleaching conditions are given in Table 3 .

After the above processes, test papers were produced from the pulp obtained, and calendering was applied to these test papers at a pressure of 20 bar and a temperature of $100{ }^{\circ} \mathrm{C}$.

\section{Optical and physical tests}

Finally, the optical and physical properties of the obtained test papers were determined. The paper samples were subjected to physical and optical tests in accordance with the corresponding standards (shown in Table 4) after conditioning for 48 hours in an air conditioning room, at a room temperature of $25 \pm 1{ }^{\circ} \mathrm{C}$ and a relative humidity of $55 \pm 1 \%$. The optical parameters of the handsheets were measured by a Datacolor Elrepho spectrophotometer.

\section{RESULTS AND DISCUSSION}

The physical properties of the first-stage recycled laboratory test paper, produced as a standard after flotation, bleaching and calendaring processes, are listed in Table 5. According to the TS 11610: 2017 standard, the minimum values for the physical properties required for $80 \mathrm{~g}$ writing paper are described in Table $6 .{ }^{19}$ When examining the results tabulated in Table 5, it may be noted that the physical properties of the test paper produced after the first recycling stage are above those required by the standards. 


\section{UFUK YILMAZ et al.}

The optical properties of the first-stage recycled pulp are given in Table 7. The reason for bleaching the pulp is to provide paper with the desired level of brightness. Again, according to the TS 11610: 2017 standard, the brightness value of $80 \mathrm{~g}$ writing paper should be of $86 \%$. The pulp obtained in the present study after the first stage of recycling reached a brightness value of $86.01 \%$ after double-stage bleaching.
Table 8 provides the fiber classification results for the pulp subjected to the first stage of recycling. In the fiber classification process, 10 grams of fully dry pulp were used. After sieving, a total of $7.538 \mathrm{~g}$ of fiber remained in all the sieves, while $2.462 \mathrm{~g}$ of fiber was determined as fines.

Table 4

Standards for optical and physical tests applied for handsheets

\begin{tabular}{ll}
\hline Optical and physical tests & Standards \\
\hline Grammage $\left(\mathrm{g} / \mathrm{m}^{2}\right)$ & TAPPI T $410 \mathrm{om}-88$ \\
Breaking length $(\mathrm{m})$ & TAPPI T 494 om-01 \\
Burst index $\left(\mathrm{kPa} \mathrm{m}^{2} / \mathrm{g}\right)$ & TAPPI T 403 om-91 \\
Tear index $\left(\mathrm{mN} \cdot \mathrm{m}^{2} \cdot \mathrm{g}\right)$ & TAPPI T $414 \mathrm{om}-88$ \\
Brightness (\% ISO) & ISO/DIS 2470 \\
Whiteness (\% ISO) & ISO 11475 \\
Yellowness (E313) & ASTM E313 \\
ERIC (PPM) & ISO 22754 \\
CIE-Whiteness $\left(\mathrm{D} 65 / 10^{\circ}\right)$ & ISO 11475 \\
$\mathrm{L}^{*}, \mathrm{a}^{*}$ and $\mathrm{b}^{*}\left(\mathrm{D} 65 / 10^{\circ}\right)$ & ISO 5631-2 \\
\hline
\end{tabular}

Table 5

Physical properties of the first-stage recycled pulps

\begin{tabular}{|c|c|c|c|c|c|c|}
\hline $\begin{array}{c}\text { Grammage } \\
\left(\mathrm{g} / \mathrm{m}^{2}\right)\end{array}$ & $\begin{array}{l}\text { Breaking } \\
\text { length }(\mathrm{m})\end{array}$ & $\begin{array}{l}\text { Burst index } \\
\left(\mathrm{kPa} \mathrm{m}^{2} / \mathrm{g}\right)\end{array}$ & $\begin{array}{l}\text { Tear index } \\
\left(\mathrm{mN} \cdot \mathrm{m}^{2} \cdot \mathrm{g}\right)\end{array}$ & $\begin{array}{l}\text { Air permeability } \\
\left(\mathrm{m}^{3} / \mathrm{dk}\right)\end{array}$ & $\begin{array}{l}\text { Density } \\
\left(\mathrm{g} / \mathrm{cm}^{3}\right)\end{array}$ & $\begin{array}{c}\text { Bulk } \\
\left(\mathrm{cm}^{3} / \mathrm{g}\right)\end{array}$ \\
\hline 88 & 5465 & 3.38 & 6.36 & 242.90 & 0.61 & 1.59 \\
\hline
\end{tabular}

Table 6

Physical properties of $80 \mathrm{~g}$ writing paper according to TS 11610: 2017 standard

\begin{tabular}{cccc}
\hline $\begin{array}{c}\text { Breaking length } \\
(\mathrm{m})\end{array}$ & $\begin{array}{c}\text { Burst index } \\
(\mathrm{kPa} \mathrm{m} / \mathrm{g})\end{array}$ & $\begin{array}{c}\text { Bulk } \\
\left(\mathrm{cm}^{3} / \mathrm{g}\right)\end{array}$ & $\begin{array}{c}\text { Density } \\
\left(\mathrm{g} / \mathrm{cm}^{3}\right)\end{array}$ \\
\hline $2000-4000$ & 1.3 & $1.2-1.5$ & $0.6-0.8$ \\
\hline
\end{tabular}

Table 7

Optical properties of the first-stage recycled pulps

\begin{tabular}{ccccccccc}
\hline $\begin{array}{c}\text { Whiteness } \\
(\% \text { ISO })\end{array}$ & $\begin{array}{c}\text { Brightness } \\
(\% \text { ISO })\end{array}$ & $\begin{array}{c}\text { Yellowness } \\
(\text { E313 })\end{array}$ & $\begin{array}{c}\text { CIE } \\
\text { Whiteness }\end{array}$ & $\mathrm{L}^{*}$ & $\mathrm{a}^{*}$ & $\mathrm{~b}^{*}$ & Opacity & $\begin{array}{c}\text { ERIC } \\
(\mathrm{PPM})\end{array}$ \\
\hline 73.4 & 86.01 & -20.11 & 124.99 & 88.61 & 3.67 & -10.86 & 97.55 & 251.92 \\
\hline
\end{tabular}

Table 8

Fiber classification results for the first-stage recycled pulps

\begin{tabular}{ccccccc}
\hline $\begin{array}{c}16 \text { mesh } \\
(\mathrm{g})\end{array}$ & $\begin{array}{c}30 \text { mesh } \\
(\mathrm{g})\end{array}$ & $\begin{array}{c}50 \text { mesh } \\
(\mathrm{g})\end{array}$ & $\begin{array}{c}100 \text { mesh } \\
(\mathrm{g})\end{array}$ & $\begin{array}{c}200 \text { mesh } \\
(\mathrm{g})\end{array}$ & $\begin{array}{c}\text { Total } \\
(\mathrm{g})\end{array}$ & $\begin{array}{c}\text { Fines } \\
(\mathrm{g})\end{array}$ \\
\hline 0.255 & 3.099 & 1.77 & 2.095 & 0.319 & 7.538 & 2.462 \\
\hline
\end{tabular}

Table 9 shows the physical properties of the pulps subjected to the second stage of recycling.
Comparing the data in Table 6 and Table 9, it may be seen that there is a $4 \%$ reduction in the 
breaking length after the second recycling stage. Likewise, when the burst index values are examined, a $4.5 \%$ decrease at the end of the second recycling stage is determined. Also, at this stage, there is a $3.1 \%$ decrease in the tear index values. On the other hand, the air permeability of the test paper obtained at the end of the second recycling stage increased by $3.1 \%$.

The optical properties of the second-stage recycled paper are given in Table 10. When comparing the optical parameters listed in Tables 7 and 10, it may be noted that there is an increase in the whiteness values of the second-stage recycled paper, although the brightness values reach approximately the same level. Also, a decrease in the opacity value of the paper can be determined, compared to the opacity value at the end of the first recycling stage. The ERIC (effective residual ink concentration) value gives the amount of ink trapped in the pulp as PPM. While the ERIC value is 251.92 PPM at the end of the first recycling stage, it decreased by $48 \%$ at the end of the second recycling stage and displayed a value of 160.56. In addition, it is observed that the whiteness values increased when the recycling was repeated, while the CIE whiteness value decreased. When examining the $\mathrm{L}^{*} \mathrm{a}^{*} \mathrm{~b}^{*}$ values, it may be remarked that there is an increase in the $\mathrm{L}^{*}$ and $\mathrm{b}^{*}$ values in the paper recycled twice, compared to that recycled once, as well as a gradual decrease in the $\mathrm{a}^{*}$ values.

Table 11 shows the fiber classification results of the second-stage recycled pulp. When comparing the data listed in Table 11 with those in Table 8, it may be observed that the fiber dimensions decrease after the second recycling run, thus less fiber was collected on the 30 and 50 mesh sieves, while more was collected on the 200 mesh one. Also, there is a slight increase in the amount of fines.

Table 12 shows the physical properties of the handsheets made from the third-stage recycled pulps. When examining the results listed in Tables 6, 9 and 12, a decrease in the breaking length, burst index and tear index of the test paper produced at the end of each recycling stage is detected, along with an increase in air permeability. The reduction in breaking length was of about $4 \%$ at the end of the second recycling stage, and about $9 \%$ after the third recycling stage, compared to the first stage.

Table 9

Physical properties of the second-stage recycled pulps

\begin{tabular}{ccccccc}
\hline $\begin{array}{c}\text { Grammage } \\
\left(\mathrm{g} / \mathrm{m}^{2}\right)\end{array}$ & $\begin{array}{c}\text { Breaking } \\
\text { length }(\mathrm{m})\end{array}$ & $\begin{array}{c}\text { Burst index } \\
(\mathrm{kPa} \mathrm{m} / \mathrm{g})\end{array}$ & $\begin{array}{c}\text { Tear index } \\
\left(\mathrm{mN} \cdot \mathrm{m}^{2} \cdot \mathrm{g}\right)\end{array}$ & $\begin{array}{c}\text { Air permeability } \\
\left(\mathrm{m}^{3} / \mathrm{dk}\right)\end{array}$ & $\begin{array}{c}\text { Density } \\
\left(\mathrm{g} / \mathrm{cm}^{3}\right)\end{array}$ & $\begin{array}{c}\text { Bulk } \\
\left(\mathrm{cm}^{3} / \mathrm{g}\right)\end{array}$ \\
\hline 88 & 5300 & 3.23 & 6.23 & 250.51 & 0.62 & 1.57 \\
\hline
\end{tabular}

Table 10

Optical properties of the second-stage recycled pulps

\begin{tabular}{ccccccccc}
\hline $\begin{array}{c}\text { Whiteness } \\
(\% \text { ISO })\end{array}$ & $\begin{array}{c}\text { Brightness } \\
(\% \text { ISO })\end{array}$ & $\begin{array}{c}\text { Yellowness } \\
(\text { E313 })\end{array}$ & $\begin{array}{c}\text { CIE } \\
\text { Whiteness }\end{array}$ & $\mathrm{L}^{*}$ & $\mathrm{a}^{*}$ & $\mathrm{~b}^{*}$ & Opacity & $\begin{array}{c}\text { ERIC } \\
(\mathrm{PPM})\end{array}$ \\
\hline 76.32 & 86.07 & -14.77 & 114.1 & 90.01 & 2.7 & -8.02 & 95.57 & 160.56 \\
\hline
\end{tabular}

Table 11

Fiber classification results for the second-stage recycled pulps

\begin{tabular}{ccccccc}
\hline $\begin{array}{c}16 \text { mesh } \\
(\mathrm{g})\end{array}$ & $\begin{array}{c}30 \text { mesh } \\
(\mathrm{g})\end{array}$ & $\begin{array}{c}50 \text { mesh } \\
(\mathrm{g})\end{array}$ & $\begin{array}{c}100 \text { mesh } \\
(\mathrm{g})\end{array}$ & $\begin{array}{c}200 \text { mesh } \\
(\mathrm{g})\end{array}$ & $\begin{array}{c}\text { Total } \\
(\mathrm{g})\end{array}$ & $\begin{array}{c}\text { Fines } \\
(\mathrm{g})\end{array}$ \\
\hline 0.512 & 2.454 & 1.107 & 1.686 & 1.733 & 7.492 & 2.508 \\
\hline
\end{tabular}

Table 12

Physical properties of the third-stage recycled pulps

\begin{tabular}{ccccccc}
\hline $\begin{array}{c}\text { Grammage } \\
\left(\mathrm{g} / \mathrm{m}^{2}\right)\end{array}$ & $\begin{array}{c}\text { Breaking } \\
\text { length }(\mathrm{m})\end{array}$ & $\begin{array}{c}\text { Burst index } \\
(\mathrm{kPa} \mathrm{m} / \mathrm{g})\end{array}$ & $\begin{array}{c}\text { Tear index } \\
\left(\mathrm{mN} \cdot \mathrm{m}^{2} \cdot \mathrm{g}\right)\end{array}$ & $\begin{array}{c}\text { Air permeability } \\
\left(\mathrm{m}^{3} / \mathrm{dk}\right)\end{array}$ & $\begin{array}{c}\text { Density } \\
\left(\mathrm{g} / \mathrm{cm}^{3}\right)\end{array}$ & $\begin{array}{c}\text { Bulkiness } \\
\left(\mathrm{cm}^{3} / \mathrm{g}\right)\end{array}$ \\
\hline 88 & 4956 & 2.84 & 5.73 & 670.01 & 0.62 & 1.58 \\
\hline
\end{tabular}


Table 13

Optical properties of the third-stage recycled pulps

\begin{tabular}{ccccccccc}
\hline $\begin{array}{c}\text { Whiteness } \\
(\% \text { ISO })\end{array}$ & $\begin{array}{c}\text { Brightness } \\
(\% \text { ISO })\end{array}$ & $\begin{array}{c}\text { Yellowness } \\
(\text { E313 })\end{array}$ & $\begin{array}{c}\text { CIE } \\
\text { Whiteness }\end{array}$ & $\mathrm{L}^{*}$ & $\mathrm{a}^{*}$ & $\mathrm{~b}^{*}$ & Opacity & $\begin{array}{c}\text { ERIC } \\
(\mathrm{PPM})\end{array}$ \\
\hline 78.24 & 86.11 & -9.01 & 101.58 & 90.89 & 1.51 & -4.98 & 94.57 & 135.56 \\
\hline
\end{tabular}

Table 14

Fiber classification results for the third-stage recycled pulps

\begin{tabular}{ccccccc}
\hline $\begin{array}{c}16 \text { mesh } \\
(\mathrm{g})\end{array}$ & $\begin{array}{c}30 \text { mesh } \\
(\mathrm{g})\end{array}$ & $\begin{array}{c}50 \text { mesh } \\
(\mathrm{g})\end{array}$ & $\begin{array}{c}100 \text { mesh } \\
(\mathrm{g})\end{array}$ & $\begin{array}{c}200 \text { mesh } \\
(\mathrm{g})\end{array}$ & $\begin{array}{c}\text { Total } \\
(\mathrm{g})\end{array}$ & $\begin{array}{c}\text { Fines } \\
(\mathrm{g})\end{array}$ \\
\hline 0.27 & 0.793 & 0.467 & 1.888 & 2.166 & 5.584 & 4.416 \\
\hline
\end{tabular}

While the decrease in the burst index value is $4.5 \%$ at the end of the second recycling stage, it increased to $16 \%$ after the third recycling stage, compared to the first stage. The decrease in the tear index value is of $3.1 \%$ at the end of the second recycling stage, while it was approximately $10 \%$ after the third recycling stage, compared to the first stage. While the air permeability of the test paper obtained at the end of the second recycling stage increased by $3.1 \%$, compared to the first stage, it boosted to $175 \%$ at the end of the third recycling stage, with a huge difference from the value of the first stage.

Table 13 shows the optical properties of the recycled pulp after the third run. Comparing Tables 7, 10 and 13, it can be observed that, after the third recycling stage, the brightness has reached a value close to the minimum threshold required by the standard, even after double-stage bleaching. In addition, as in the previous recycling stages, it is observed that, as the number of recycling runs is increased, the whiteness values also rise, while the CIE whiteness value decreases. The opacity value, on the other hand, continued its gradual downward trend, reaching 94.57, with a $1 \%$ decrease compared to the previous stage. The ERIC value decreased by approximately $16 \%$, compared to that of the second recycling stage. When examining the $\mathrm{L}^{*}$ $a^{*} b^{*}$ values, the increase in $L^{*}$ and $b^{*}$ values continued, similarly to the trend of the previous recycling stages, along with a gradual decrease in a* values.

Examining the fiber classification results in Table 14, it may be noted that, after the third recycling stage, the amount of fiber accumulated in the 100-200 mesh sieves constitutes approximately $73 \%$ of the total fiber amount. A comparative analysis of the fiber size distribution shown in Tables 8, 11 and 14, reveals that, after each recycling stage, the fiber sizes decreased, while the amount of fines rose dramatically. Thus, after the third recycling stage, the amount of fines constituted approximately $44 \%$ of the total fiber amount.

During the recycling process of waste paper, cellulose undergoes structural changes, as a result of which its water-swelling property is altered irreversibly. Because of these changes, the flexibility and plasticization of the fibers are lost. $^{20}$ When cellulose pulps are turned into handsheets, the cell walls of the cellulose collapse during the wet pressing and drying processes to which handsheets are subjected during papermaking, causing the degradation of cellulose. This situation negatively affects the hydrogen bonds, while weaker hydrogen bonds mean lower strength properties of the paper. As reported earlier, with an increasing number of recycling runs, the crystallinity of cellulose and the average width of crystallites increased, leading to a swelling restriction of the fibers, which finally resulted in strength loss. ${ }^{22}$

In addition, the strength properties of recycled and remanufactured papers diminish because of the presence of a high amount of short fibers in the pulp. ${ }^{10-14,17-21}$ According to the literature, waste paper can be recycled 5 or 6 times, but in each recycle, it loses from 15 to 20 percent of long fibers. ${ }^{23}$ According to the fiber classification results in this study, at the end of the third recycling stage, the fiber sizes decreased considerably and most of the fibers remained in the 200 mesh sieve. At the end of the third recycling stage, more than $44 \%$ of the pulp used for the fiber size distribution analysis turned into fines. 


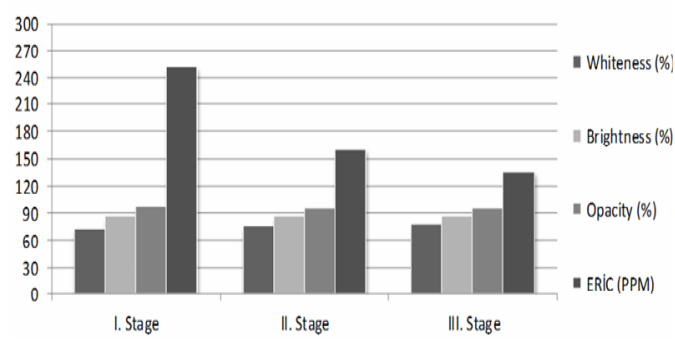

Figure 2: Evolution of optical properties during the recycling stages

\section{CONCLUSION}

The results of this study demonstrated that fibers exposed to chemicals, high temperature and drying processes during the recycling procedure gradually lose their resistance properties, thus confirming earlier published literature on this subject.

A gradual decrease in the tensile, burst and tearing strength of the paper produced after each recycling stage was noticed, while the air permeability increased after the second recycling stage. It can be supposed that the air permeability of the paper is related to bulk density. However, it has been remarked that the air permeability value continues to increase, even though the bulk density values are close to each other in all three recycling runs. According to the fiber classification results, at the end of the third recycling stage, the fiber sizes decreased considerably and most of the fibers remained in the 200 mesh sieve. Thus, more than $44 \%$ of the pulp used in the analysis turned into fines.

Also, it has been observed that, as the number of recycling runs increases, the opacity value of the paper decreases. This could possibly be explained by the increasing crystallinity of cellulose and average width of the crystallites with the increase in the number of recycling runs. As regards the $L^{*} a^{*} b^{*}$ values, it was determined that throughout the recycling stages, there is an increase in the $\mathrm{L}^{*}$ and $\mathrm{b}^{*}$ values, and a gradual decrease in the $a^{*}$ values. This indicates that the paper gradually turns from dark to light, from red to green and from blue to yellow. Also, with a rising number of recycling runs, there is a gradual increase in the whiteness values, along with a decrease in CIE whiteness values. Finally, ERIC values also decreased throughout the recycling stages. Considering the findings regarding the ERIC and optical values, it can be concluded that

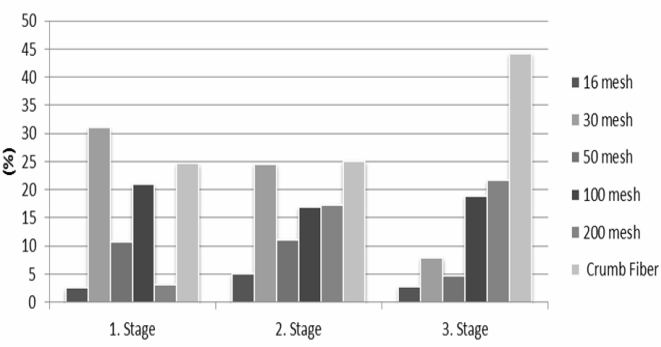

Figure 3: Evolution of fiber size during the recycling stages

the more often the paper is recycled, the more successfully the ink is removed from the fibers.

Overall, the findings of the present work confirm the results reported in published literature. Repeated recycling of cellulosic materials can contribute to protecting the environment and can bring significant benefits to the economy of countries. However, to ensure the feasibility of the recycling process and to ensure the repeated use of waste paper in paper production, deep knowledge of paper properties under the effects of recycling is necessary.

ACKNOWLEDGEMENTS: The authors thank the Kahramanmaraş Sütçü İmam University Scientific Research Projects Unit for supporting this study with the project number 2019/1-13D.

\section{REFERENCES}

1 ISO, "Kağıt ve Kağıt Ürünleri İmalat Sanayi" [Paper and Paper Products Manufacturing], Istanbul, 2018,

https://www.iso.org.tr/sites/1/upload/files/kagit_sektor u_raporu_web_kasim2018-9076.pdf

${ }^{2}$ R. W. J. McKinney (Ed.), "Technology of Paper Recycling", edited by R.W.J. McKinney, Blackie A\&P, 1995, p. 401

3 EPA, "Paper and Paperboard: Material-Specific Data", (U.S., 2018), available at https://www.epa.gov/facts-and-figures-aboutmaterials-waste-and-recycling/paper-and-paperboardmaterial-specific-data

${ }_{4}$ M. Türemen, A. Demir and E. Özdoğan, J. Eng. Sci., $\quad \mathbf{2 5}, \quad 805 \quad$ (2018), https://dergipark.org.tr/tr/download/article-file/900077

5 C. Leduc, L. M. L. Roch and C. Daneault, Cellulose Chem. Technol., 45, 657 (2011), https://cellulosechemtechnol.ro/pdf/CCT45,910(2011)/p.657-663.pdf

6 R. Mauchaufé, S. J. Lee, I. Han, S. H. Kim and S. Y. Moon, Nature Sci. Rep., 9, 14046 (2019), https://doi.org/10.1038/s41598-019-50495-4 
7 D. Tutak, Cellulose Chem. Technol., 51, 483 (2015),

https://www.cellulosechemtechnol.ro/pdf/CCT56(2017)/p.483-488.pdf

8 M. Vukoje and M. Rožıćvarıous, Cellulose Chem. Technol., $\quad 52, \quad 515 \quad$ (2018), https://www.cellulosechemtechnol.ro/pdf/CCT78(2018)/p.515-541.pdf

9 T. Lindström, L. Wågberg and T. Larsson, in Procs. $13^{\text {th }}$ Fundamental Research Symposium, Cambridge, UK, September 4-9, 2005, pp. 457-562, https://bioresources.cnr.ncsu.edu/wpcontent/uploads/2020/07/2005.1.457.pdf

10 Š. Šutý, K. Petriláková, S. Katuščák, S. Kirschnerová, M. Jablonský et al., Cellulose Chem. Technol., $\quad 46, \quad 631 \quad$ (2012), https://www.cellulosechemtechnol.ro/pdf/CCT46,910(2012)/p.631-635.pdf

11 M. A. Hubbe, R. A. Vendetti and O. J. Rojas, BioResources, 2, 739 (2007), https://doi.org/10.15376/BIORES.2.4.739-788

12 M. Beaumont, J. Konig, M. Opietnik, A. Potthast and T. Rosenau, Cellulose, 24, 1199, (2017), https://doi.org/10.1007/s10570-016-1166-9

13 U. Weise, T. Maloney and H. Paulapuro, Cellulose, 3, 189 (1996), https://doi.org/10.1007/BF02228801

14 M. Nazhad and L. Paszner, TAPPI J., 77, 171 (1994), https://doi.org/10.1016/0141-0229(94)00057-X

15 O. C. M. Lima, N. C. Pereira and M. A. L. S. Machado, Braz. J. Chem. Eng., 17, 539 (2000), https://www.scielo.br/j/bjce/a/6g4Wjn6RpBmRwZGr G6pjpRs/?lang=en

16 O. C. M. Lima, N. C. Pereira and M. A. L. S. Machado, Acta Scientiarum, 22, 1229 (2000),
https://periodicos.uem.br/ojs/index.php/ActaSciTechno 1/article/view/3055/2212

17 B. Blaznik, D. Gregor-Svetec and S. Bračko, Cellulose Chem. Technol., 51, 755 (2017), https://www.cellulosechemtechnol.ro/pdf/CCT78(2017)/p.755-764.pdf

18 U. Y1lmaz, A. Tutus and S. Sönmez, in Procs. The Third International Printing Technologies Symposium, Istanbul, October 10-12, 2019, pp. 296-301, http://www.printistanbul.org/2019/wp-

content/uploads/2020/01/Printistanbul_Bildiri_Kitabi_ 2019_S.pdf

${ }_{19}$ M. Çiçekler, PhD Thesis, Kahramanmaraş Sütçü İmam University, Institute of Science, Kahramanmaraş, Turkey, 2019, p. 137, https://tez.yok.gov.tr/UlusalTezMerkezi/tezDetay.jsp?i $\mathrm{d}=\mathrm{vRGDaLDJ}$ xyEkn_I1QFPxog\&no=NVOXRZBybn 3dflkO03Uukg

20 H. T. Şahin, Süleyman Demirel University Journal of the Faculty of Forestry, 14, 74 (2013), https://dergipark.org.tr/tr/download/article-file/195823

21 H. T. Şahin, Süleyman Demirel University Journal of the Faculty of Forestry, 15, 183 (2014), https://dergipark.org.tr/tr/download/article-file/195865

22 Y. Chen, J. Wan, Q. Wu, Y. Ma and M. Huang, Cellulose Chem. Technol., 50, 1061 (2016), https://cellulosechemtechnol.ro/pdf/CCT910(2016)/p.1061-1067.pdf

23 J. B. Benitez, M. E. T. Koga, M. L. O. D. Almeida, F. E. Felissia, S. W. Park et al., O Papel, 75, 54 (2014), http://www.revistaopapel.org.br/noticiaanexos/1405694418_aa9dbfd2d1e311e1efa41bf23fa16 589_300616195.pdf 